\title{
THE EVALUATION OF THE POTENTIAL OF DEVELOPING TOURISM IN KYSUCE REGION
}

\author{
MÁRIA BARANČOKOVÁ, PETER BARANČOK
}

Institute of Landscape Ecology, SAS, Štefánikova 3, P. O. Box 254, 81499 Bratislava, Slovak Republic; e-mail: maria. barancokova@savba.sk, peter.barancok@savba.sk

\begin{abstract}
Barančoková M., Barančok P.: The evaluation of the potential of developing tourism in Kysuce region. Ekológia (Bratislava), Vol. 39, No. 4, p. 380-400, 2020.

Tourism is an industry with a strong long-term potential of becoming one of the key industries in securing the country's economic growth. Tourists are nowadays interested in not only getting to know the cultural-historical peculiarities, but also the way of life and cultural traditions of the inhabitants of the individual regions. Kysuce region is characterised by scattered settlement, which used to be a significant type of settlement in remote and inaccessible parts of the area in the past. Nowadays, however, the majority of the objects of the scattered settlement either serve as holiday chalets or are uninhabited.The aim of this paper is to evaluate the recreational potential of tourism in Kysuce region. Based on the established methodology, the individual villages were divided into five categories: areas with less suitable potential of tourism development (PTD), areas with suitable PTD, areas with quality PTD, areas with PTD of high quality and areas with the most significant PTD. These categories have been established based on the point evaluation of the potential of input indicators - natural potential, cultural-historical potential, recreational infrastructure and environmental infrastructure. The most significant PTD in the monitored area is the village of Oščadnica (279 points), and the villages of Horný Vadičov (231 points), Raková (224 points) and Nová Bystrica (219.5 points) were evaluated as the areas with PTD of high quality.

Agro-tourism in this region is, however, the least developed, despite the location of the region being very favourable for such an activity. Its development could lower unemployment and offer a source of income of the inhabitants, or reduce movement of the inhabitants into other regions of Slovakia. Subsequently, the character of the landscape with all its key functions for sustaining the quality of the environment could be preserved.
\end{abstract}

Key words: Kysuce region, sustainable development, tourism, recreation, development potential.

\section{Introduction}

Tourism is one of the most dynamic and most widespread economic industries in the world. A number of various and complex activities play their part in the process of efficient development of tourism. These activities are related to the economic, environmental, social, cultural and political sphere. Tourism, apart from its key role as a driving force of socio-economic progress, is responsible for worsening of the environment in the areas favoured by tourists and by means of influencing effects from the global point of view also on the state of the environment in a broader context. 
Slovakia does not have such dynamics of tourism growth as its neighbouring countries. In the past years, tourism in Slovakia did grow dynamically, but only from the point of view of the number of visitors, the number of overnight stays, growing turnover and so on. However, from the long-term point of view, it does not grow steadily. Stagnation is shown mainly in the decline of competitiveness as a result of the lack of investment into facilities, the need of continual investment into services of higher quality and in slow growth of employment, which is still being limited by the ever-growing expenses. Despite all this, tourism is an industry that has a significant potential in the long-term, and can be one of the key sectors securing the country's economic growth in the future.

Tourism, if well developed, can be a source of income for the villages and a source of opportunities and revitalisation of towns and villages. It is a means of increasing the standard of living, provides economic and social opportunities for all subjects interested in using it for their benefit.

A prerequisite of realization of various forms of tourism is the potential of the area, that is, what it has to offer, on which depends the interest of the client (participant, tourist, holidaymaker).

There are several terms for 'tourism', the most come from the background of geographers and economists (e.g., Kopšo, 1992; Kaspar, 1995; Butler et al., 1997; Otrubová, 2003; Veel, 2011), it describes a set of activities aimed at satisfying people's needs connected to travelling and staying away from the place of permanent residence with the aim of recovering, usually in the free time. According to authors Wokoun et al. (2008), travelling and tourism are activities whose sum represents one of the world's biggest economic industries and is becoming the biggest creator of working positions, one of the biggest export industries and a significant stimulator of investment activities.

Based on its objective, motivation and aim, (Weiss et al., 2005) tourism is divided into recreational, cultural-excursion, religious, educational, social, spa-healing, sport, getting to know nature, adventurous, professional and shopping. Based on regional categorisation of tourism in the Slovak Republic where the regions are divided into four categories, Kysuce region belongs to the Severopovažský region, which is in the I. category - areas with international significance. Kmeco (2016) analysed the potential of the individual regions by setting up certain criteria, which were evaluated by points. For each region, 19 most common activities typical for tourism in Slovakia were evaluated. The potential was evaluated by four levels: basic, average, good, high.

The components of tourism as a key concept are also recreation, ecotourism, rural tourism, agrotourism and others. Vaníček (2001) considers recreation to be such an activity during which weakened physical and mental forces are strengthened by daily, weekly, seasonal or annual rhythm, in mental but mainly physical form. Rural tourism and agro-tourism are nowadays quite frequent terms not only among academics, but also among the wide public. Rural tourism is a type of tourism away from recreational and tourist centres, and it can be characterised as a set of recreational, or free-time activities, that are connected to the environment of the rural settlement and these activities are different from urban recreational activities (Habán, Otapka, 2004). Rural tourism is defined as a set of activities connected to the return to the nature, with the possibility of staying with the families, that is, staying in 
the rural environment. According to Pásková, Zelenka (2012), agrotourism is a tourist or recreational stay on a family farm in rural environment that will introduce an alternative way of life in nature to the visitors. Participation in agricultural activities, or getting to know the original techniques of the production of food and animal husbandry is very important. Another part is active rest in the form of hiking or cycling, horseback riding and so on. Getting to know the cultural traditions, especially the peculiarities of the individual regions, is nowadays considered one of the most profitable industries. The interest of a nowadays' tourist is not only getting to know the cultural-historical peculiarities, but also the way of life and cultural traditions of the inhabitants of the individual regions. Apart from seaside resorts, tourists are looking for the ecologically clean, untouched by industry, remote corners with relatively preserved cultural traditions, saved from unification tendencies of the globalised world. Ecotourism is a form of sustainable tourism aimed mostly at natural areas with regard to keeping the negative impact on the individual environment and lifestyle of the local inhabitants to the minimum (Matlovičová et al., 2015). Ecotourism cannot be a mass issue because mass tourism usually brings with itself harming of the environment and significant change to the way of life of the local inhabitants.

Several authors in Slovakia and in the neighbouring countries have dealt with the evaluation of the tourism potential for the development of recreation, tourism and regional development, that is, Bartkowski (1977), Warszyńska (1979), Mariot (1983), Bína (2002), Novotná (2007) Nováková, Frantál (2007), Klapka et al. (2008) Pawlusinski, Piziak (2009), Rosič, Klamár (2009), Molitoris, Pavlíčková (2013), Gajdoš, Trnková (2016), Gregorová, Korec (2017) and others. Trukhachev (2015) analyses the potential, challenges and problems of rural tourism from the point of view of its impact on sustainability of the countryside. He studies alternative sources of income for the country people via tourism and explores the effect of rural tourism on agriculture in the local rural communities. Green infrastructure plays an important role in recreation and in people's satisfaction, mainly in urban and suburban areas (Năstase et al., 2019). In the past years, natural areas have become preferable recreational areas for people who want to escape their busy city life. Recreation activities in natural areas, for example, in natural parks, should respect the environment to ensure balance, and they should not have a negative effect on the environment (Cetin, Sevik, 2016).

Veselý, Dohnal (2015) represent in their paper a qualitative model of tourism that comprises of various variables, including biodiversity, change in flora composition in affected biotopes, or animals used by tourists. Drábová-Degro, Krnáčová (2017) suggest an ecological model of tourism aimed at the evaluation of suitability of location, selective realisation and environmental prerequisites of the landscape for the individual forms of tourism that represent recreational (cultural) services.

Tourism in Kysuce region is done mostly in the rural environment. Emphasis is put on the connection of the man with nature and on renewal of the coexistence of the man and nature; that is why, we can classify it as a form of green tourism. Kysuce belong to regions with rich cultural-historical potential and relatively still intact natural formations, but at the same time with often poor complexity of services, weaker promotion, worse mutual coordination of business and administrative (approving) activities.

The most significant tourism centre in Kysuce is Oščadnica - Velká Rača, which is one 
of the biggest ski resorts in Slovakia. The majority of tourists come here during the winter season. During the summer season, there are fewer tourists, although there is satisfactory potential for visits in the forest or rural environment. This is why, it is necessary to build more facilities that would attract visitors in summertime and during the mid-season (Michniak, 2010).

The aim of the paper is to determine the recreation potential of the Kysuce region based on natural, cultural-historical and infrastructure characteristics. This area is characterised by scattered type of settlement - kopanice, that were a significant type of settlement in remote and inaccessible parts of the area in the past. Nowadays, however, the majority of the scattered objects serve as holiday chalets or are uninhabited.

\section{Methodology}

The monitored area was marked as a natural whole unit of the river basin of Kysuce River (Fig. 1) that includes the district of Čadca ( 3 towns and 20 villages), the district of Kysucké Nové Mesto (1 town and 13 villages), and a part of the district of Žilina (Lutiše village). The biggest settlements are towns Čadca with 25,000, Kysucké Nové Mesto with 16,000, Turzovka with 7,700 and Krásno nad Kysucou with 6,900 inhabitants.

Based on the division of Slovakia into geomorphological units (Mazúr, Lukniš, 1986), this monitored area belongs to three areas: Stredné Beskydy Mts. (units Kysucká vrchovina Mts., Kysucké Beskydy Mts., Podbeskydská vrchovina Mts., Oravská Magura Mts. and Oravské Beskydy Mts. - they take up 28,218 ha of the area), Západné Beskydy Mts. (units Jablunkovské medzihorie Mts., Moravsko-sliezske Beskydy Mts. and Turzovská vrchovina Mts. - they take up 29,467 ha of the area) and Slovensko-moravské Karpaty Mts. (unit Javorníky Mts. - it takes up 22,980 ha of the area).

Evaluating the potential of the development of tourism comprises of evaluating the input indicators; in our case, it is the natural and cultural-historical potential (NCHP) and recreational and environmental infrastructure (REI). The methodology of the authors Anděl et al. (2008) was used for evaluating, since it was modified for the needs of

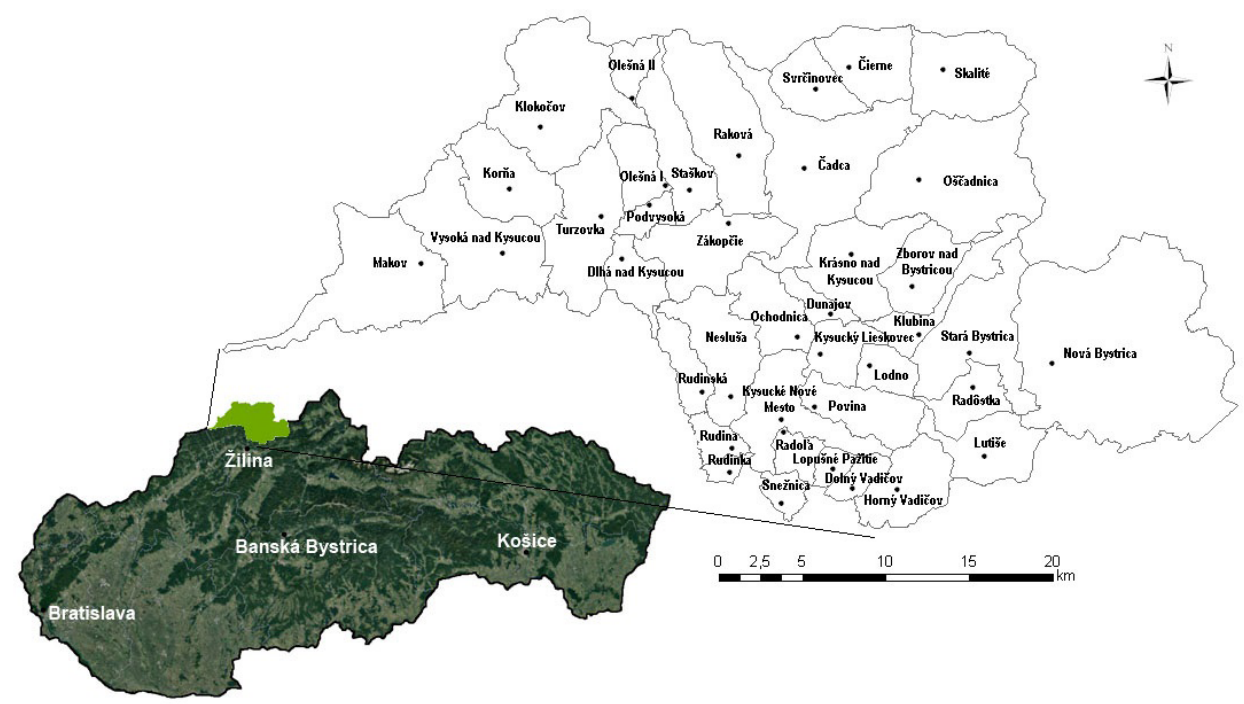

Fig. 1. Monitored area - the Kysuce region. 
evaluating the problems in the monitored area and captures its character and peculiarities. Natural potential of the area was evaluated based on CORINE land cover database from 2018. For evaluating the occurrence and classification of the protected areas, materials from The National protection of Nature of SR (www.biomonitoring.sk, www. sopsr.sk) were used. Cultural-historical potential characterising the attractiveness of tourism in the individual areas was evaluated based on Mišúnová-Šulavíková (2002), The Monuments Board of the SR (PÚSR, 2015) and from the data of the individual villages and organisations operating in the region. Recreational and environmental infrastructure was evaluated based on the data from the town and village statistics, using the local plans, the program of economic and social development of the villages).

In the monitored area, the following tourism-recreational activities (TRA) were identified; they are already running, or the area has potential for their application:

a. hiking $(\mathrm{H})$,

b. cycling $(\mathrm{C})$,

c. rural tourism $(\mathrm{R})$,

d. $\operatorname{agrotourism}(\mathrm{A})$,

e. ecotourism (E),

f. winter tourism (downhill and cross-country skiing) (W),

g. unspecified tourism (U) - cross-country skiing on unkept trails, flying, paragliding, horseback riding.

Also, in the monitored area, the following types of contemporary landscape structure were earmarked - forests (FO), meadows and pastures (MP), mosaic structures (MS), where the components of historical structure of the agricultural land play the main role, including the historical scattered settlement, arable land (AL) and the components of tertiary landscape structure - protected areas (PA) and cultural and historical monuments (CHM) that significantly affect the potential of the given area for the development of green tourism - are considered the indicators of development. Each indicator affects the individual recreational activities individually.

The evaluation of the potential for the development of green tourism was divided into four steps:

\section{Characteristics and categories of indicators (CI) of natural and cultural-historical potential (NCHP)}

NCHP indicators were divided into individual categories. Each category was given point value from 1 to 4 , where 4 is the best value ( 4 points) based on the following key:

Forests (FO) - categories FO1 to FO4 are given in GIS as the measure of the surface of the forest area in the area of interest of the village to the total surface of the village in percentage: FO1 [0\%, 25\%], FO2 [25\%, 50\%], FO3 [50\%, 75\%], FO4 > 75\%.

Meadows and pastures (MP) - categories MP1 to MP4, Mosaics structures (MS) - categories MS1 to MS4 and Arable land (AL) - categories AL1 to AL4 - all categories are given in GIS as the measure of the surface of the individual categories in the area of interest of the village to the total surface of the village in percentage:

MP1, MS1, AL1 $[0 \%, 10 \%]$

MP2, MS2, AL2 [10\%, 20\%]

MP3, MS3, AL3 [20\%, 30\%]

MP4, MS4, AL4 > 30\%.

Protected areas $(P A)$ - the total sum of the protected areas was evaluated according to the data from The State Nature Conservancy of the SR; categories PA1 to PA4 are defined based on the number of protected areas in the cadastral area: PA $1=1$ protected area, PA $2=2$ protected areas, PA $3=3$ or 4 protected areas, PA $4=5$ or more protected areas.

Cultural-historical monuments (CHM) - the total sum of the monuments was evaluated according to the map of cultural-historical activity of tourism (Mišúnová-Šulavíková, 2002) and the internet sources; categories CHM1 to $\mathrm{CHM} 4$ are defined based on the number of cultural-historical monuments: CHM1 $=1$ monument, CHM2 $=2$ or 3 monuments, $\mathrm{CHM} 3=4$ or 5 monuments, $\mathrm{CHM} 4=\geq 6$ monuments.

\section{Determining the weight of the indicators (WI) of natural and cultural-historical potential}

In this step, we assigned importance to NCHP indicators from 1 to 4 (where 4 is the best) based on the recreational activity that is possible to be performed there. It means that if, for example, the forest coverage in the cadastral area was above $75 \%$, the indicator was evaluated in FO4 category and was given the value 4 . Forest environment is very significant from the point of view of hiking; that is why, the value of this recreational activity in the forest environment was given a 4 . The final point value will thus be a multiple of the point value of the category indicator and the weight of the indicator, here it will be 16 . 
The weight of the indicators is given in Table 1 . The value $\mathrm{x}$ means that the given indicator is not significant for the given recreational activity. From the point of view of recreational and environmental indicators, we have worked with the uniform significance $=1$.

T a b l e 1. Weight of the indicators of natural and cultural-historical potential of tourism (Anděl et al., 2008 - modified)

\begin{tabular}{|c|c|c|c|c|c|c|c|c|}
\hline \multirow{3}{*}{$\begin{array}{l}\text { Natural and cultural- } \\
\text { historical potential } \\
\text { (NCHP) }\end{array}$} & \multicolumn{8}{|c|}{ Recreational activities and their weight for the individual categories of indicators } \\
\hline & \multirow{2}{*}{$\begin{array}{l}\text { Hiking } \\
\text { (H) }\end{array}$} & \multirow{2}{*}{$\begin{array}{l}\text { Cycling } \\
\text { (C) }\end{array}$} & \multirow{2}{*}{$\begin{array}{l}\text { Rural } \\
\text { tourism } \\
(\mathrm{R})\end{array}$} & \multirow{2}{*}{$\begin{array}{l}\text { Agro- } \\
\text { tourism } \\
\text { (A) }\end{array}$} & \multirow{2}{*}{$\begin{array}{l}\text { Eco- } \\
\text { tourism } \\
(\mathrm{E})\end{array}$} & \multicolumn{2}{|c|}{$\begin{array}{c}\text { Winter tourism } \\
\text { (W) }\end{array}$} & \multirow{2}{*}{$\begin{array}{l}\text { Unspeci- } \\
\text { fied tour- } \\
\text { ism (U) }\end{array}$} \\
\hline & & & & & & $\mathbf{W 1}^{*}$ & $\mathbf{W} 2^{\star *}$ & \\
\hline Forests (FO) & 4 & 3 & 2 & 1 & 4 & $\mathrm{x}$ & 2 & 2 \\
\hline $\begin{array}{l}\text { Meadows and pastures } \\
\text { (MP) }\end{array}$ & 3 & 2 & 3 & 4 & 4 & 3 & 3 & 2 \\
\hline Mosaic structures (MS) & 2 & 1 & 2 & 4 & 2 & $\mathrm{x}$ & 1 & 1 \\
\hline Arable land (AL) & 1 & 1 & 2 & 3 & 2 & $\mathrm{x}$ & 2 & 1 \\
\hline Protected areas (PA) & 3 & 2 & 2 & $\mathrm{x}$ & 3 & $\mathrm{x}$ & $\mathrm{x}$ & $\mathrm{x}$ \\
\hline $\begin{array}{l}\text { Cultural and historical } \\
\text { monuments (CHM) }\end{array}$ & 3 & 2 & 3 & $\mathrm{x}$ & 3 & $\mathrm{x}$ & $\mathrm{x}$ & $\mathrm{x}$ \\
\hline
\end{tabular}

Notes: $\mathrm{W} 1^{\star}$ - downhill skiing; W2** - cross-country skiing.

\section{Defining numerical values of natural and cultural-historical potential (NCHP)}

For the individual TRA (H, C, R, A, E, W or U) values of the potential for tourism-recreational activities (PTRA) were calculated for each indicator (FO, MP, MS, AL, PA or CHM). Numerical values of the PTRA for individual recreational activities in each category of the indicator (forests, meadows and pastures, etc.) were calculated according to the pattern: PTRA $=\mathrm{CI}_{n} \cdot \mathrm{WI}_{\mathrm{n}}$, where $\mathrm{CI}$ is the category of the indicator with its point value 1 to 4 and $\mathrm{WI}$ is the weight of the indicator with its point value 1 to 4 .

Therefore, for example, for the cadastral area of Čadca town (Table 2), indicators in the given categories are as follows - FO2, MP1, MS3, AL1, PA4, CHM1 - and then TRA Hiking (H) has the total value:

$\mathrm{PTRA}_{\mathrm{H}}=\mathrm{CI}_{\mathrm{FO}} \cdot \mathrm{WI}_{\mathrm{FO}}+\mathrm{CI}_{\mathrm{MP}} \cdot \mathrm{WI}_{\mathrm{MP}}+\mathrm{CI}_{\mathrm{MS}} \cdot \mathrm{WI}_{\mathrm{MS}}+\mathrm{CI}_{\mathrm{AL}} \cdot \mathrm{WI}_{\mathrm{AL}}+\mathrm{CI}_{\mathrm{PA}} \cdot \mathrm{WI}_{\mathrm{PA}}+\mathrm{CI}_{\mathrm{CHM}} \cdot \mathrm{WI}_{\mathrm{CHM}}=2 \cdot 4+1 \cdot 3+3$ $\cdot 2+1 \cdot 1+4 \cdot 3+1 \cdot 3=8+3+6+1+12+3=33$

In this manner, numerical values of all TRA in individual villages of the monitored area were calculated (Table 2). The sum total of PTRA values for all TRA in the village area $\left(\mathrm{NCHP}_{\text {village }}=\mathrm{PTRA}_{\mathrm{H}}+\mathrm{PTRA}_{\mathrm{C}}+\mathrm{PTRA}_{\mathrm{R}}+\mathrm{PTRA}_{\mathrm{A}}\right.$ $+\mathrm{PTRA}_{\mathrm{E}}+\mathrm{PTRA}_{\mathrm{W} 1+\mathrm{W}_{2}}+\mathrm{PTRA}_{\mathrm{U}}$ ) is in the last column of Table 2.

The sum total of the point values of the individual recreational activities in all the categories of an indicator represents the total point value NCHP for the given village. The higher this point value is, the higher NCHP for the development of tourism the village has.

\section{Characteristics and evaluation of recreational and environmental infrastructure (REI)}

In recreational infrastructure, the following indicators were evaluated: boarding facilities, information centres, tourist trails, sport facilities, cultural and educational facilities. During evaluating, each unit of the indicator was assigned one point.

From the environmental infrastructure, indicators such as public plumbing, sewerage network and handling with communal waste were evaluated. Depending on the village having a given point from infrastructure, indicators were assigned half a point or a whole point during evaluation.

To evaluate the potential of the landscape for a given activity means to express the ability, or suitability of the landscape for realisation of individual socio-economic activities in accordance with harmonious functioning of relationships of the landscape ecosystem. Also, it is important to take into consideration that the existing anthropogenies activities in the area affect the potential usage of natural characteristics. Evaluating the contemporary state of the recreational potential comprises of evaluating the suitability of the natural conditions for realisation of recreational activities and evaluating socio-economic conditions for the realisation of recreational activities. The evaluation of the total potential of the area, that is, a certain offer of the possibilities for realisation of recreational 
activities (Izakovičová, 2010) is done by synthesis of the two aforementioned points (natural and socio-economic potential). In the paper, we have divided the evaluation of the potential for the development of tourism into evaluating natural and cultural-historical potential (NCHP) and into recreational and environmental infrastructure (REI).

NCHP represents a potential that invites the visitors, provides them with forms of recreation, recuperation, getting to know new natural beauties and cultural-historical monuments; it offers them means of new enjoyment that they do not have in the area of their permanent residence, which offers them possibilities for self-realisation, and so on. The more similar options there are, the more attractive the area is for visitors.

\section{Results and discussion}

Evaluating NCHP always has to be realised in connection with the protection of nature and landscape and socio-economic aspects. Nowadays, however, the development of tourism is often in conflict with the interests of nature and landscape protection. In the monitored area, there is a large-scale protected landscape area Kysuce (PLA Kysuce), 23 small-scale protected areas of the national network declared in categories national nature reserve ( $3 \mathrm{NNR}$ ), nature reserve (10 NR), nature monument (9 NM) and protected site (1 PS), 20 special areas of conservation (SAC, areas of European interest) and 2 special protected areas (SPA, protected bird areas) - SPA Malá Fatra and SPA Horná Orava extend into the area (in the village Nová Bystrica). SAC and SPA are a part of the network of European protected areas Natura 2000. Apart from this, there are 18 protected trees in the areas of Čadca and Kysucké Nové Mesto districts. Such a high number of protected areas also confirms high NCHP of the monitored area.

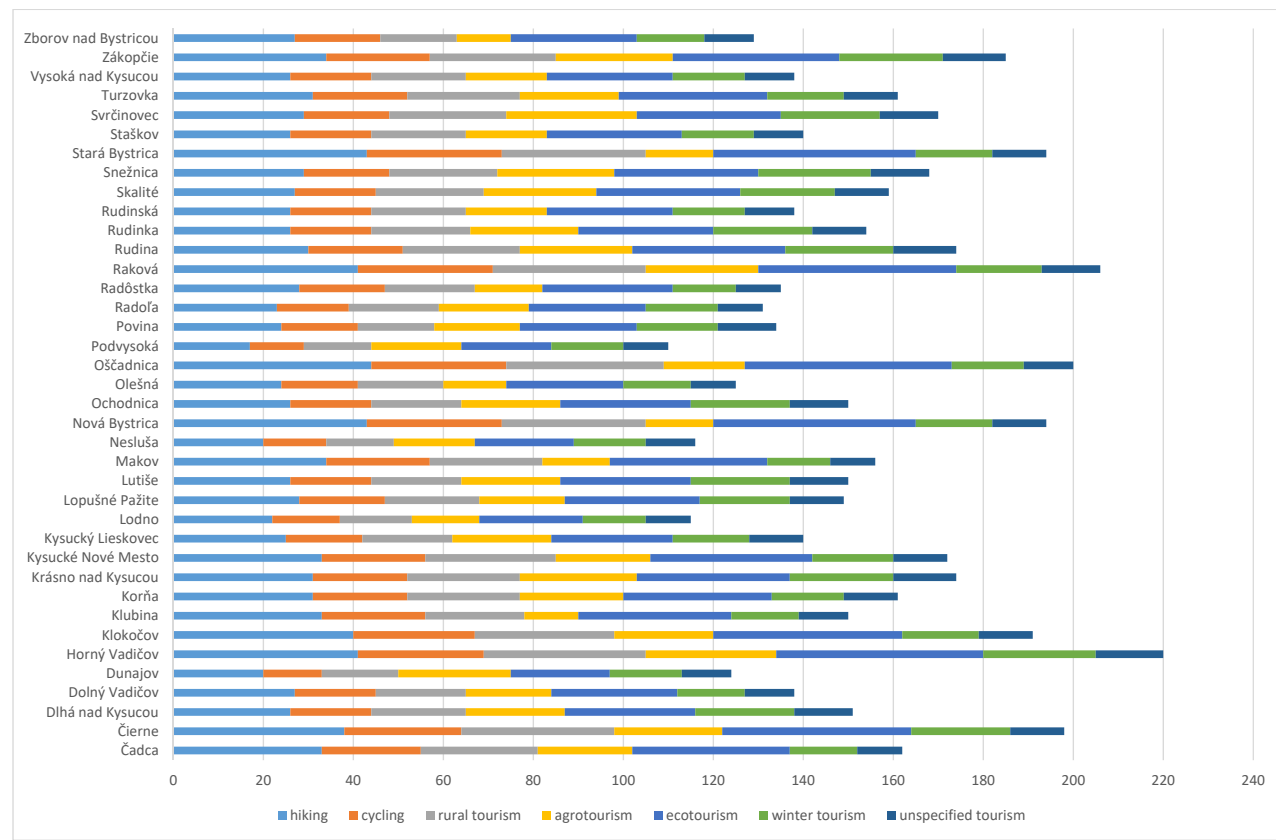

Fig. 2. Occurrence of the individual recreational activities in municipalities of Kysuce region and point evaluation of natural and cultural-historical potential. 
Results of the NCHP evaluation of tourism are stated in Table 2 and Fig. 2. With regards to the overall character of the monitored area, natural conditions and representation of the areas significant from the point of view of natural protection, some villages have similar NCHP for the development of tourism. The resulting numerical values of NCHP for individual villages reached values 110 to 220 points. Based on these points, the villages were divided into three categories:

a. areas with low NCHP (110-146 points),

b. areas with middle NCHP (147-183 points),

c. areas with high NCHP (184-220 points).

These categories were determined based on the point evaluation of hiking, cycling, rural tourism, agrotourism, ecotourism, winter tourism and other types of recreational usage of the area. The deciding position in NCHP evaluation in the monitored area belongs to hiking, cycling, rural tourism ecotourism and winter tourism.

Based on the point evaluation, 8 villages have high NCHP for tourism: Horný Vadičov (220 points), Raková (206 points), Oščadnica (200 points), Čierne (198 points), Nová Bystrica and Stará Bystrica (each 194 points), Klokočov (191 points) and Zákopčie (185 points) (Fig. 2). These areas have the highest potential not only for hiking, rural tourism, ecotourism, but also for cycling. Villages such as Horný Vadičov. Snežnica, Zákopčie, Rudina, Svrčinovec and the town Krásno nad Kysucou have a high potential for agrotourism and winter tourism.

The majority of the monitored area (12 villages and 4 towns, $42 \%$ of all villages) belongs to the category with middle NCHP for tourism, 9 villages in Čadca district, 6 villages in Kysucké Nové Mesto district and village Lutiše belonging to Žilina district. In the western part of the area, there are villages Korňa (161 points), Makov (156 points) and Dlhá nad Kysucou (151 points) and the town Turzovka (161 points). From these, Makov, Korňa and the town Turzovka have the highest potential for hiking, cycling, rural tourism and ecotourism. The village Dlhá nad Kysucou has potential mainly for agrotourism and winter tourism.

In the central and eastern part of the area, towns Krásno nad Kysucou (174 points) and Čadca (162 points), villages Svrčinovec (170 points), Skalité (159 points), Klubina (150 points) and Ochodnica (150 points) belong to this category. Towns Čadca and Krásno nad Kysucou and village Klubina have potential for hiking, cycling and eco-tourism. Krásno nad Kysucou, Svrčinovec, Skalité and Ochodnica have potential for development of agrotourism and winter tourism.

In the southern part of the monitored area, Kysucké Nové Mesto (172 points), villages Rudina (174 points), Snežnica (168 points), Rudinka (154 points), Lutiše (150 points) and Lopušné Pažite (149 points) belong to the category of middle NCHP for tourism. Kysucké Nové Mesto, Rudina and Snežnica have a significant potential for the development of hiking, ecotourism, cycling and rural tourism. Rudina, Rudinka and Snežnica villages have potential for the development of agrotourism and winter tourism.

Fourteen villages, 7 from Čadca and 7 from Kysucké Nové Mesto districts were classified into the category of low NCHP of tourism. From Čadca district, it is worth mentioning the villages Staškov, Radôstka, Zborov nad Bystricou and Vysoká nad Kysucou that have potential for ecotourism, cycling, rural tourism and hiking. From Kysucké Nové Mesto district villages Dolný Vadičov, Rudinská and Kysucký Lieskovec have potential for hiking, cycling and ecotourism, village Radola for agrotourism and village Povina for winter tourism. 
T a b le 2. Evaluation of natural and cultural-historical potential (NCHP).

\begin{tabular}{|c|c|c|c|c|c|c|c|c|c|}
\hline \multirow[t]{2}{*}{ Village } & \multirow[t]{2}{*}{ Indicators / category } & \multicolumn{7}{|c|}{$\begin{array}{l}\text { Value of potential of tourism- } \\
\text { recreational activities (PTRA) } \\
\text { for individual tourism- } \\
\text { recreational activities (TRA) }\end{array}$} & \multirow[t]{2}{*}{$\begin{array}{c}\text { Point evaluation } \\
\text { NCHP }\end{array}$} \\
\hline & & $\mathbf{H}$ & $\mathbf{C}$ & $\mathbf{R}$ & $\mathbf{A}$ & $\mathbf{E}$ & $\mathbf{W}$ & $\mathbf{U}$ & \\
\hline Čadca & $\begin{array}{l}\text { FO2, MP1, MS3, AL1, } \\
\text { PA4, CHM1 }\end{array}$ & 33 & 22 & 26 & 21 & 35 & 15 & 10 & 162 \\
\hline Čierne & $\begin{array}{l}\mathrm{FO} 2, \mathrm{MP} 2, \mathrm{MS} 2, \mathrm{AL} 2, \\
\mathrm{PA} 2, \mathrm{CHM} 4\end{array}$ & 38 & 26 & 34 & 24 & 42 & 22 & 12 & 198 \\
\hline Dlhá nad Kysucou & $\begin{array}{l}\text { FO3, MP2, MS2, AL1, } \\
\text { PA0, CHM1 }\end{array}$ & 26 & 18 & 21 & 22 & 29 & 22 & 13 & 151 \\
\hline Dolný Vadičov & $\begin{array}{l}\text { FO3, MP1, MS3, AL0, } \\
\text { PA1, CHM1 }\end{array}$ & 27 & 18 & 20 & 19 & 28 & 15 & 11 & 138 \\
\hline Dunajov & $\begin{array}{l}\text { FO2, MP1, MS4, AL1, } \\
\text { PA0, CHM0 }\end{array}$ & 20 & 13 & 17 & 25 & 22 & 16 & 11 & 124 \\
\hline Horný Vadičov & $\begin{array}{l}\text { FO3, MP2, MS3, AL2, } \\
\text { PA1, CHM4 }\end{array}$ & 41 & 28 & 36 & 29 & 46 & 25 & 15 & 220 \\
\hline Klokočov & $\begin{array}{l}\text { FO3, MP1, MS3, AL1, } \\
\text { PA4, CHM2 }\end{array}$ & 40 & 27 & 31 & 22 & 42 & 17 & 12 & 191 \\
\hline Klubina & $\begin{array}{l}\text { FO4, MP1, MS1, AL0, } \\
\text { PA3, CHM1 }\end{array}$ & 33 & 23 & 22 & 12 & 34 & 15 & 11 & 150 \\
\hline Korňa & $\begin{array}{l}\text { FO3, MP1, MS4, AL0, } \\
\text { PA1, CHM2 }\end{array}$ & 32 & 21 & 25 & 23 & 33 & 16 & 12 & 162 \\
\hline Krásno nad Kysucou & $\begin{array}{l}\text { FO3, MP2, MS3, AL1, } \\
\text { PA1, CHM1 }\end{array}$ & 31 & 21 & 25 & 26 & 34 & 23 & 14 & 174 \\
\hline Kysucké Nové Mesto & $\begin{array}{l}\text { FO3, MP1, MS2, AL2, } \\
\text { PA0, CHM4 }\end{array}$ & 33 & 23 & 29 & 21 & 36 & 18 & 12 & 172 \\
\hline Kysucký Lieskovec & $\begin{array}{l}\text { FO3, MP1, MS3, AL1, } \\
\text { PA0, CHM1 }\end{array}$ & 25 & 17 & 20 & 22 & 27 & 17 & 12 & 140 \\
\hline Lodno & $\begin{array}{l}\text { FO3, MP1, MS2, AL0, } \\
\text { PA0, CHM1 }\end{array}$ & 22 & 15 & 16 & 15 & 23 & 14 & 10 & 115 \\
\hline Lopušné Pažite & $\begin{array}{l}\text { FO3, MP2, MS2, AL0, } \\
\text { PA1, CHM1 }\end{array}$ & 28 & 19 & 21 & 19 & 30 & 20 & 12 & 149 \\
\hline Lutiše & $\begin{array}{l}\text { FO3, MP2, MS2, AL1, } \\
\text { PA1, CHM0 }\end{array}$ & 26 & 18 & 20 & 22 & 29 & 22 & 13 & 150 \\
\hline Makov & $\begin{array}{l}\text { FO3, MP1, MS2, AL0, } \\
\text { PA3, CHM2 }\end{array}$ & 34 & 23 & 25 & 15 & 35 & 14 & 10 & 156 \\
\hline Nesluša & $\begin{array}{l}\text { FO3, MP1, MS2, AL1, } \\
\text { PA0, CHM0 }\end{array}$ & 20 & 14 & 15 & 18 & 22 & 16 & 11 & 116 \\
\hline Nová Bystrica & $\begin{array}{l}\text { FO4, MP1, MS1, AL1, } \\
\text { PA4, CHM3 }\end{array}$ & 43 & 30 & 32 & 15 & 45 & 17 & 12 & 194 \\
\hline Ochodnica & $\begin{array}{l}\text { FO3, MP2, MS2, AL1, } \\
\text { PA1, CHM0 }\end{array}$ & 26 & 18 & 20 & 22 & 29 & 22 & 13 & 150 \\
\hline Olešná & $\begin{array}{l}\text { FO3, MP1, MS1, AL1, } \\
\text { PA0, CHM2 }\end{array}$ & 24 & 17 & 19 & 14 & 26 & 15 & 10 & 125 \\
\hline Oščadnica & $\begin{array}{l}\text { FO3, MP1, MS2, AL1, } \\
\text { PA4, CHM4 }\end{array}$ & 44 & 30 & 35 & 18 & 46 & 16 & 11 & 200 \\
\hline
\end{tabular}


$\mathrm{T}$ a b le 2. Evaluation of natural and cultural-historical potential (NCHP) - continuation.

\begin{tabular}{|c|c|c|c|c|c|c|c|c|c|}
\hline \multirow[t]{2}{*}{ Village } & \multirow[t]{2}{*}{ Indicators / category } & \multicolumn{7}{|c|}{$\begin{array}{l}\text { Value of potential of tourism- } \\
\text { recreational activities (PTRA) } \\
\text { for individual tourism- } \\
\text { recreational activities (TRA) }\end{array}$} & \multirow[t]{2}{*}{$\begin{array}{c}\text { Point evaluation } \\
\text { NCHP }\end{array}$} \\
\hline & & H & $\mathbf{C}$ & $\mathbf{R}$ & $\mathbf{A}$ & $\mathbf{E}$ & $\mathbf{W}$ & $\mathbf{U}$ & \\
\hline Podvysoká & $\begin{array}{l}\text { FO2, MP1, MS2, AL2, } \\
\text { PA0, CHM0 }\end{array}$ & 17 & 12 & 15 & 20 & 20 & 16 & 10 & 110 \\
\hline Povina & $\begin{array}{l}\text { FO4, MP1, MS2, AL1, } \\
\text { PA0, CHM0 }\end{array}$ & 24 & 17 & 17 & 19 & 26 & 18 & 13 & 134 \\
\hline Radol'a & $\begin{array}{l}\text { FO2, MP1, MS2, AL2, } \\
\text { PA1, CHM1 }\end{array}$ & 23 & 16 & 20 & 20 & 26 & 16 & 10 & 131 \\
\hline Radôstka & $\begin{array}{l}\text { FO3, MP1, MS2, AL0, } \\
\text { PA2, CHM1 }\end{array}$ & 28 & 19 & 20 & 15 & 29 & 14 & 10 & 135 \\
\hline Raková & $\begin{array}{l}\text { FO3, MP1, MS3, AL2, } \\
\text { PA3, CHM3 }\end{array}$ & 41 & 30 & 34 & 25 & 44 & 19 & 13 & 206 \\
\hline Rudina & $\begin{array}{l}\text { FO3, MP2, MS2, AL2, } \\
\text { PA0, CHM2 }\end{array}$ & 30 & 21 & 26 & 25 & 34 & 24 & 14 & 174 \\
\hline Rudinka & $\begin{array}{l}\text { FO2, MP2, MS2, AL2, } \\
\text { PA2, CHM0 }\end{array}$ & 26 & 18 & 22 & 24 & 30 & 22 & 12 & 154 \\
\hline Rudinská & $\begin{array}{l}\text { FO3, MP1, MS2, AL1, } \\
\text { PA0, CHM2 }\end{array}$ & 26 & 18 & 21 & 18 & 28 & 16 & 11 & 138 \\
\hline Skalité & $\begin{array}{l}\text { FO2, MP2, MS3, AL1, } \\
\text { PA0, CHM2 }\end{array}$ & 27 & 20 & 24 & 25 & 32 & 21 & 12 & 161 \\
\hline Snežnica & $\begin{array}{l}\text { FO2, MP3, MS3, AL0, } \\
\text { PA1, CHM1 }\end{array}$ & 29 & 19 & 24 & 26 & 32 & 25 & 13 & 168 \\
\hline Stará Bystrica & $\begin{array}{l}\text { FO4, MP1, MS1, AL1, } \\
\text { PA4, CHM3 }\end{array}$ & 43 & 30 & 32 & 15 & 45 & 17 & 12 & 194 \\
\hline Staškov & $\begin{array}{l}\text { FO3, MP1, MS2, AL1, } \\
\text { PA0, CHM2 }\end{array}$ & 26 & 18 & 21 & 18 & 30 & 16 & 11 & 140 \\
\hline Svrčinovec & $\begin{array}{l}\text { FO2, MP2, MS4, AL1, } \\
\text { PA0, CHM2 }\end{array}$ & 29 & 19 & 26 & 29 & 32 & 22 & 13 & 170 \\
\hline Turzovka & $\begin{array}{l}\text { FO3, MP1, MS3, AL1, } \\
\text { PA1, CHM2 }\end{array}$ & 31 & 21 & 25 & 22 & 33 & 17 & 12 & 161 \\
\hline Vysoká nad Kysucou & $\begin{array}{l}\text { FO3, MP1, MS2, AL1, } \\
\text { PA0, CHM2 }\end{array}$ & 26 & 18 & 21 & 18 & 28 & 16 & 11 & 138 \\
\hline Zákopčie & $\begin{array}{l}\text { FO3, MP2, MS3, AL1, } \\
\text { PA1, CHM2 }\end{array}$ & 34 & 23 & 28 & 26 & 37 & 23 & 14 & 185 \\
\hline Zborov nad Bystricou & $\begin{array}{l}\text { FO4, MP1, MS1, AL0, } \\
\text { PA2, CHM0 }\end{array}$ & 27 & 19 & 17 & 12 & 28 & 15 & 11 & 129 \\
\hline
\end{tabular}

Infrastructure in itself means a supporting structure with the purpose to serve to sustain another structure according to the people's interest. Recreational potential of the area represents a sum of ecological, cultural and social factors, possibilities, abilities and prerequisites of the landscape or a certain territorial unit to offer its visitor adequate conditions for recreational usage. Primary social recreational potential comprises of buildings and recreation facilities (primary recreational potential represented by the factors of the natural background 
was evaluated in the previous chapter), secondary recreational potential represents the capacity of the offered services in the recreational place or target place and tertiary recreational potential represents institutionalised base, such as the character and organisational structure of the recreation. Stadiums, sports halls, gyms, shooting ranges and other indoor or outdoor sports centres are classified as sport-recreational infrastructure. REI elements provide its visitors certain comfort during their stay in the area: whether there is enough lodging with standard or of higher standard facilities, whether the area also offers sports and cultural enjoyment, whether there are enough suitably regulated and located tourist or cycling trails, whether there is enough information about the recreational possibilities or local events and so on.

One of the factors influencing the level of development and competitiveness of the regions, quality of life and standard of living of the inhabitants is the accessibility of quality environmental infrastructure. Equipment of the area by environmental infrastructure makes the area more attractive to the inhabitants and has a positive impact on its health and standard of living. It also creates conditions for tourism and hospitality services, investment and potential for development of private and public sector. Environmental infrastructure, mainly systems of water supply, sewerage, collecting and disposal of waste, are the elements that are of high importance for attracting investors, employment growth and regional competitiveness and they highly contribute to the comfort of the stay in the area.

When evaluating REI, we have proceeded from the point evaluation of its individual indicators. Based on the total value, the villages were divided into:

a. areas with less developed infrastructure (0-9 points)

b. areas with developed infrastructure (10-19 points)

c. areas with the most developed infrastructure (more than 20 points)

The results of the evaluation of recreational and environmental infrastructure are given in Table 3 and Fig. 3. The most developed REI is in towns Čadca, Kysucké Nové Mesto and villages Oščadnica, Makov, Nová Bystrica. Villages Oščadnica and Makov are areas with developed lodging capacities (developed ski resorts) and tourist tracks. Village Oščadnica reaches 79 points in the evaluation, which is significantly higher in comparison with the other villages. It is because it provides 59 lodging facilities and 12 tourist trails with overall length of $45 \mathrm{~km}$. Another village with the most developed infrastructure is village Makov (43 points). There is the highest number of tourist trails (32), with the overall length of 98 $\mathrm{km}$, which is the maximum from the whole Kysuce region. Towns Čadca and Kysucké Nové Mesto and villages Nová Bystrica were also put into this category. The towns offer enough lodging facilities and tourist trails (12) with the overall length of $52 \mathrm{~km}$. Village Nová Bystrica has well-developed recreational infrastructure, it has 12 tourist trails $48 \mathrm{~km}$ long and also offers lodging capacities, however, the environmental infrastructure has not been developed in the whole village.

Twenty villages (53\% of all the villages) were classified into the category of developed REI. These areas have 96 tourist trails altogether, with the overall length of $287 \mathrm{~km}$. Villages Klokočov and Vysoká nad Kysucou have the most -8 tourist trails each with the length of $67 \mathrm{~km}$. All the villages in this category (apart from town Krásna nad Kysucou) have welldeveloped environmental infrastructure. Krásno nad Kysucou town does not have finished sewerage network of Industrial Water Treatment in all its area. 
T a b l e 3. Evaluating recreational and environmental infrastructure (REI).

\begin{tabular}{|c|c|c|c|c|c|c|c|c|c|c|c|}
\hline \multirow[t]{2}{*}{ Village } & \multicolumn{6}{|c|}{$\begin{array}{c}\text { Recreational } \\
\text { infrastructure }\end{array}$} & \multicolumn{4}{|c|}{$\begin{array}{l}\text { Environmental } \\
\text { infrastructure }\end{array}$} & \multirow[t]{2}{*}{ TOTAL } \\
\hline & LF & IC & TT & SF & $\mathrm{CU}$ & total & WA & SE & CW & total & \\
\hline Čadca & 15 & 1 & 8 & 3 & 5 & 32 & 1 & 1 & 1 & 3 & 35 \\
\hline Čierne & 3 & 0 & 1 & 1 & 4 & 9 & 1 & 1 & 1 & 3 & 12 \\
\hline Dlhá nad Kysucou & 2 & 0 & 6 & 1 & 0 & 9 & 1 & 1 & 1 & 3 & 12 \\
\hline Dolný Vadičov & 1 & 0 & 3 & 1 & 1 & 6 & 1 & 1 & 1 & 3 & 9 \\
\hline Dunajov & 1 & 0 & 1 & 2 & 1 & 5 & 0 & 0 & 1 & 1 & 6 \\
\hline Horný Vadičov & 1 & 0 & 4 & 2 & 1 & 8 & 1 & 1 & 1 & 3 & 11 \\
\hline Klokočov & 3 & 0 & 8 & 2 & 1 & 14 & 0.5 & 0.5 & 1 & 2 & 16 \\
\hline Klubina & 3 & 0 & 6 & 1 & 1 & 11 & 1 & 1 & 1 & 3 & 14 \\
\hline Korňa & 4 & 0 & 5 & 1 & 1 & 11 & 1 & 1 & 1 & 3 & 14 \\
\hline Krásno nad Kysucou & 3 & 0 & 4 & 3 & 2 & 12 & 1 & 0.5 & 1 & 2.5 & 14.5 \\
\hline Kysucké Nové Mesto & 6 & 0 & 4 & 5 & 7 & 22 & 1 & 1 & 1 & 3 & 25 \\
\hline Kysucký Lieskovec & 1 & 0 & 1 & 2 & 1 & 5 & 1 & 1 & 1 & 3 & 8 \\
\hline Lodno & 0 & 0 & 3 & 1 & 1 & 5 & 1 & 1 & 1 & 3 & 8 \\
\hline Lopušné Pažite & 0 & 0 & 1 & 1 & 0 & 2 & 1 & 1 & 1 & 3 & 5 \\
\hline Lutiše & 1 & 0 & 4 & 1 & 1 & 7 & 0 & 0 & 1 & 1 & 8 \\
\hline Makov & 6 & 0 & 32 & 1 & 1 & 40 & 1 & 1 & 1 & 3 & 43 \\
\hline Nesluša & 2 & 0 & 5 & 2 & 1 & 10 & 1 & 1 & 1 & 3 & 13 \\
\hline Nová Bystrica & 6 & 0 & 14 & 1 & 2 & 23 & 1 & 0.5 & 1 & 2.5 & 25.5 \\
\hline Ochodnica & 1 & 0 & 2 & 2 & 2 & 7 & 1 & 1 & 1 & 3 & 10 \\
\hline Olešná & 0 & 0 & 4 & 1 & 2 & 7 & 1 & 1 & 1 & 3 & 10 \\
\hline Oščadnica & 59 & 1 & 12 & 2 & 2 & 76 & 1 & 1 & 1 & 3 & 79 \\
\hline Podvysoká & 0 & 0 & 1 & 1 & 0 & 2 & 1 & 1 & 1 & 3 & 5 \\
\hline Povina & 0 & 0 & 4 & 1 & 0 & 5 & 1 & 1 & 1 & 3 & 8 \\
\hline Radola & 3 & 0 & 3 & 1 & 0 & 7 & 1 & 1 & 1 & 3 & 10 \\
\hline Radôstka & 3 & 0 & 5 & 1 & 1 & 10 & 1 & 1 & 1 & 3 & 13 \\
\hline Raková & 7 & 0 & 4 & 1 & 3 & 15 & 1 & 1 & 1 & 3 & 18 \\
\hline Rudina & 0 & 0 & 0 & 1 & 1 & 2 & 1 & 1 & 1 & 3 & 5 \\
\hline Rudinka & 0 & 0 & 1 & 1 & 0 & 2 & 1 & 0 & 1 & 2 & 4 \\
\hline Rudinská & 0 & 0 & 3 & 1 & 0 & 4 & 0.5 & 0 & 1 & 1.5 & 5.5 \\
\hline Skalité & 5 & 0 & 6 & 1 & 3 & 15 & 1 & 1 & 1 & 3 & 18 \\
\hline Snežnica & 0 & 0 & 2 & 1 & 1 & 4 & 1 & 1 & 1 & 3 & 7 \\
\hline Stará Bystrica & 4 & 0 & 5 & 1 & 1 & 11 & 1 & 1 & 1 & 3 & 14 \\
\hline Staškov & 2 & 0 & 2 & 1 & 1 & 6 & 1 & 1 & 1 & 3 & 9 \\
\hline Svrčinovec & 3 & 0 & 3 & 1 & 2 & 9 & 1 & 1 & 1 & 3 & 12 \\
\hline Turzovka & 5 & 1 & 7 & 2 & 1 & 16 & 1 & 1 & 1 & 3 & 19 \\
\hline Vysoká nad Kysucou & 4 & 0 & 8 & 1 & 1 & 14 & 1 & 1 & 1 & 3 & 17 \\
\hline Zákopčie & 4 & 1 & 5 & 1 & 1 & 12 & 1 & 1 & 1 & 3 & 15 \\
\hline Zborov nad Bystricou & 1 & 0 & 5 & 1 & 2 & 9 & 1 & 1 & 1 & 3 & 12 \\
\hline
\end{tabular}

Notes: LF - the number of lodging facilities; IC - information centre; TT - number of tourist trails; SF - number of sports facilities; CU - number of cultural and educational facilities; WA - existence of public plumbing; SE - existence of sewerage in the village; $\mathrm{CW}$ - disposal of communal waste. 


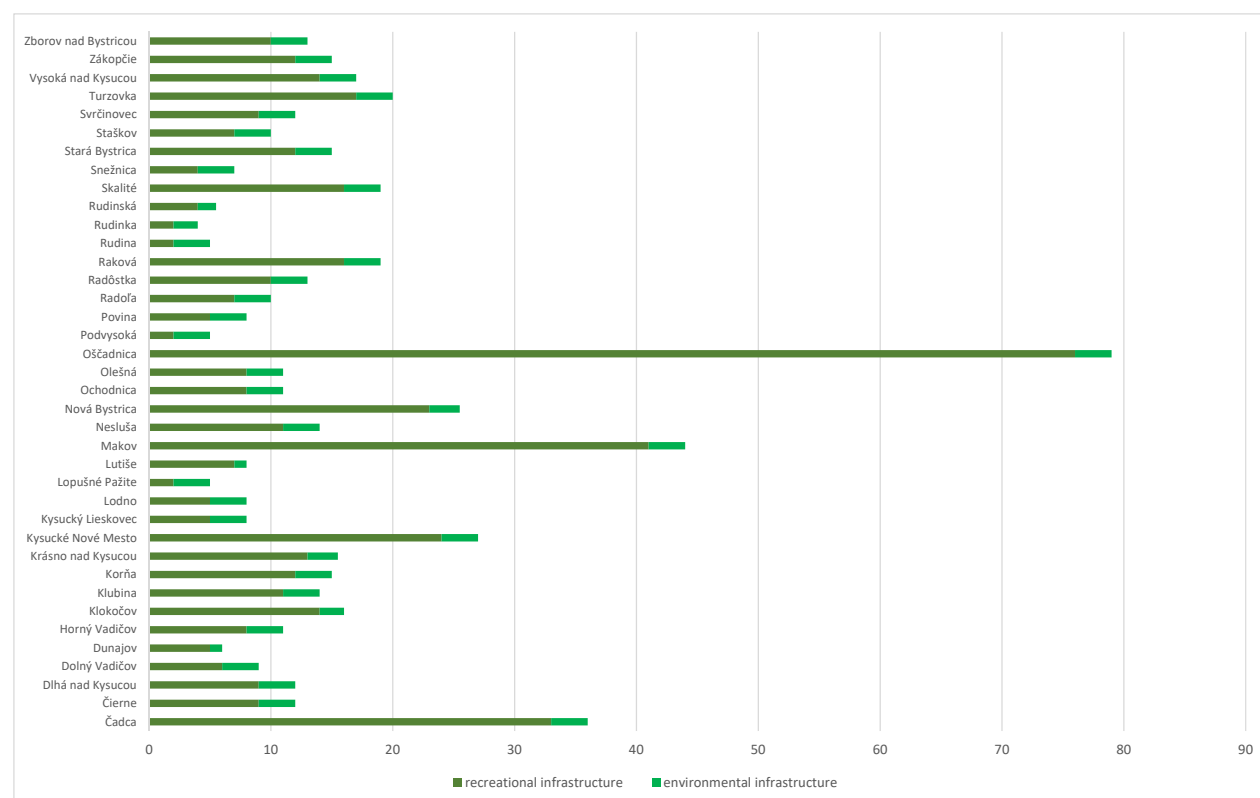

Fig. 3. Point evaluation of recreational and environmental infrastructure in municipalities of Kysuce region.

Thirteen villages were classified in the category of less developed REI. 10 villages belong to Kysucké Nové Mesto district. These are villages that have less developed recreational infrastructure and some even environmental infrastructure. Altogether, they have 17 tourist trails of cca $23 \mathrm{~km}$ length.

Overall evaluation of the potential of development of tourism (PDT) proceeded from the evaluation of natural and cultural-historical potential (NCHP) and evaluation of recreational and environmental infrastructure (REI) in the individual cadastral areas. The final NCHP was determined according to the pattern:

$\mathrm{PDT}=\mathrm{NCHP}+\mathrm{REI}$.

The results of evaluating PDT are in Table 4 and Figs 4 and 5.

Based on the final results, villages were then divided into five categories:

1. areas with small - less suitable PDT (115-147 points),

2. areas with middle high - suitable PDT (148-180 points),

3. areas with high - significant PDT (181-213 points),

4. areas with very high - very significant PDT (214-246 points),

5. areas with the highest - the most significant PDT (247-279 points).

In Kysuce region, village Oščadnica has the highest PDT (279 points) (Fig. 5). It is a good example of a village with developed tourism. It has high NCHP and the most developed REI. The area is known mostly in connection with the development of the area and building facilities for winter recreational-sports activities, but summer activities are becoming more and more common. There is a large ski resort aimed at downhill disciplines, there is the possibil- 
$\mathrm{T}$ a b l e 4. Evaluation of potential of development of tourism (PDT) in the monitored area.

\begin{tabular}{|l|c|c|c|l|c|c|c|}
\hline \multirow{2}{*}{ Village } & \multicolumn{3}{c}{ Point evaluation } & \multicolumn{2}{c}{ Village } & \multicolumn{3}{c|}{ Point evaluation } \\
\cline { 2 - 4 } \cline { 5 - 8 } & NCHP & REI & PDT & & NCHP & REI & PDT \\
\hline Čadca & 162 & 35 & 197 & Olešná & 125 & 10 & 135 \\
\hline Čierne & 198 & 12 & 210 & Oščadnica & 200 & 79 & 279 \\
\hline Dlhá nad Kysucou & 151 & 12 & 163 & Podvysoká & 110 & 5 & 115 \\
\hline Dolný Vadičov & 138 & 9 & 147 & Povina & 134 & 8 & 142 \\
\hline Dunajov & 124 & 6 & 130 & Radola & 131 & 10 & 141 \\
\hline Horný Vadičov & 220 & 11 & 231 & Radôstka & 135 & 13 & 148 \\
\hline Klokočov & 191 & 16 & 207 & Raková & 206 & 18 & 224 \\
\hline Klubina & 150 & 14 & 164 & Rudina & 174 & 5 & 179 \\
\hline Korňa & 161 & 14 & 175 & Rudinka & 154 & 4 & 158 \\
\hline Krásno nad Kysucou & 174 & 14.5 & 188.5 & Rudinská & 138 & 5.5 & 143.5 \\
\hline Kysucké Nové Mesto & 172 & 25 & 197 & Skalité & 159 & 18 & 177 \\
\hline Kysucký Lieskovec & 140 & 8 & 148 & Snežnica & 168 & 7 & 175 \\
\hline Lodno & 115 & 8 & 123 & Stará Bystrica & 194 & 14 & 208 \\
\hline Lopušné Pažite & 149 & 5 & 154 & Staškov & 140 & 9 & 149 \\
\hline Lutiše & 150 & 8 & 158 & Svrčinovec & 170 & 12 & 182 \\
\hline Makov & 156 & 43 & 199 & Turzovka & 161 & 19 & 180 \\
\hline Nesluša & 116 & 13 & 129 & $\begin{array}{l}\text { Vysoká } \\
\text { nad Kysucou }\end{array}$ & 168 & 17 & 155 \\
\hline Nová Bystrica & 194 & 25.5 & 219.5 & Zákopčie & 185 & 15 & 200 \\
\hline Ochodnica & 150 & 10 & 160 & $\begin{array}{l}\text { Zborov } \\
\text { nad Bystricou }\end{array}$ & 129 & 12 & 141 \\
\hline
\end{tabular}

ity of cross-country skiing (Kysuce ski trail), there is the longest bobsleigh track in Central Europe, rope park, trampolines, downhill cycling and others. Apart from hiking trails, there are also $54 \mathrm{~km}$ long cycling trails that range from easy and undemanding to difficult and extreme, depending on the surface and length of the trail. There is abundance of natural beauties, the most significant are on NNR Velká Rača that represents an example of preserved natural forest communities of beech, spruce and sycamore maple. Village Oščadnica relies mostly on prosperity during winter tourism, but this dependence lowers the turnout in other seasons (Otepka, Kučáková, 2010). The development of sports-recreational activities brings high potential of commodification of the landscape (Chrenka, Ira, 2011). In the context of comparing the ever-picturesque countryside of Kysuce region, the promotion of the fastgrowing resort of Oščadnica - Velká Rača is in strong contrast. You can find everything on the home page of the resort except for the depiction of rural environment. The natural environment plays here just a role of a stage, an area for sport enjoyment, which is in its nature an urban phenomenon (Chrenka, 2011).

Villages Horný Vadičov (231 points), Raková (224 points) and Nová Bystrica (219.5 points) are classified into the category of very high development of PDT (Fig. 5). All three villages have high NCHP (Table 2) and belong among the areas with developed infrastructure (Table 3), especially village Nová Bystrica that belongs among the areas with the most developed infra- 


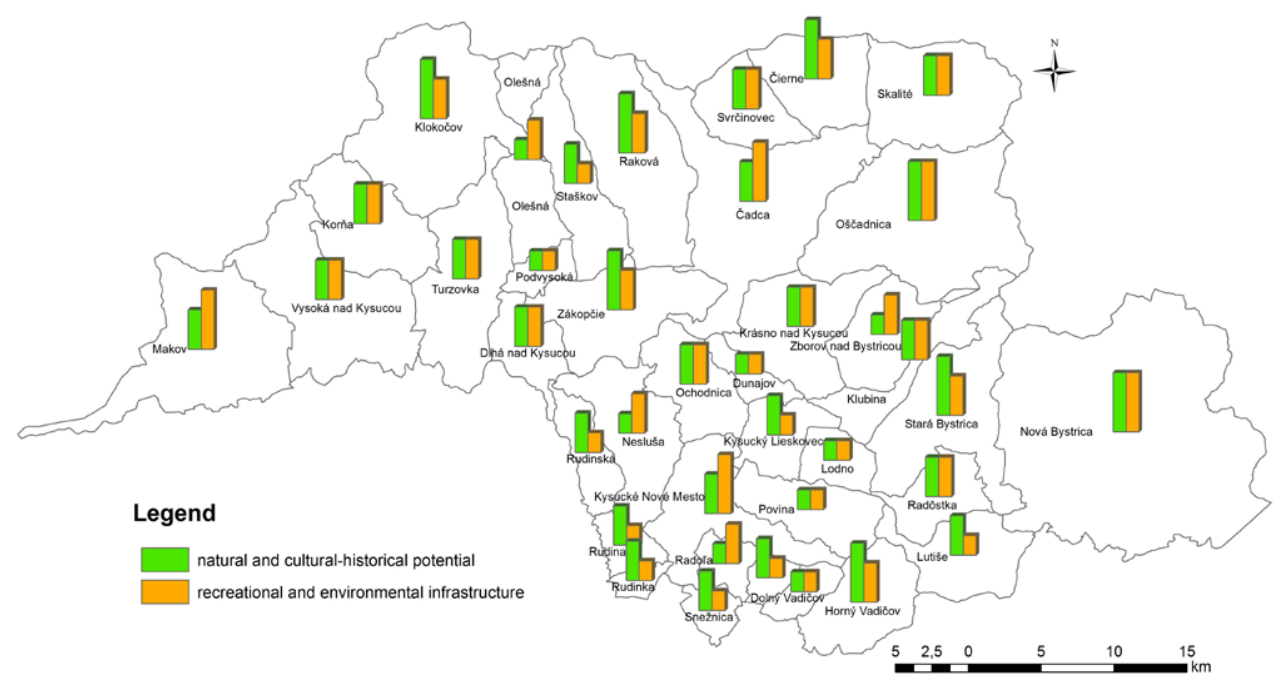

Fig. 4. Natural and cultural-historical potential and recreational and environmental infrastructure of the area.

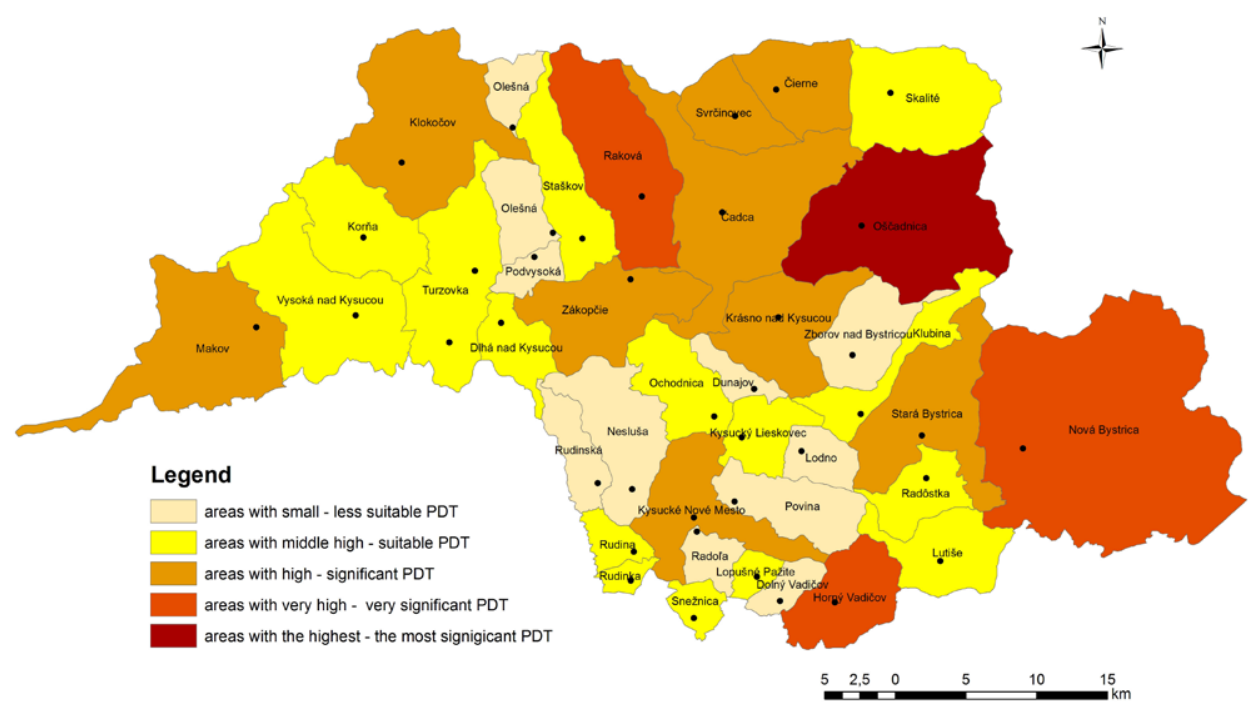

Fig. 5. Potential of development of tourism in Kysuce region.

structure. Village Horný Vadičov is located under the southern slope of klippen belt of Kysucká vrchovina Mts. There is NR Ladonhora with preserved natural calcareous forest communities and important archaeological site from early Bronze Age and late Iron Age. 
Village Raková is located in THE north-western part of the region (in the valley of Horné Kysuce) on the border of Javorníky Mts. and Turzovská vrchovina Mts. There is Nature Reservation Velký Polom where there are preserved forest communities of beech-fir spruce grove. An example of geological structure is Medvedia skala formed by alternating claystones and sandstones. Their unequal resistance towards erosion caused the existence of various rock solitaires. Cycling path of $10.3 \mathrm{~km}$ traverses the area, connecting the village with the Czech Republic. Rural tourism can be connected to horse riding. The area is known not only from the tourist point of view, but there are significant sacral memorials, various monuments and the village is the birthplace of Ján Palárik, a significant Slovak playwright, publisher, priest and agile organiser of national and literary life.

Village Nová Bystrica is located in Bystrická brázda furrow on the border of Kysucké Beskydy Mts. and Kysucká vrchovina Mts. Cycling path from Krásna nad Kysucou with more than $20 \mathrm{~km}$ traverses the village. Ethnographic exposition of Kysuce village in nature in $\mathrm{Vy}-$ chylovka that represents folk architecture and the way of life and culture of Kysuce in the second half of the $19^{\text {th }}$ century and the first half of the $20^{\text {th }}$ century is a part of the village. A part of the museum there is also a historical forest switchback railway that was established in 1926, and in 1991, it was declared a part of National Cultural Heritage. In the area, there are interesting natural creations of flysch zone located in the NM Vychylovské skálie Mts. (breakup of sandstone into massive rock blocks, located in preserved fir-beech-spruce growths) and NM Vychylovské prahy Mts. (typical threshold flow of a mountain river through rock layers of claystone and sandstones).

Six villages and 3 towns were classified into the category with high PDT. Villages Čierne (210 points), Stará Bystrica (208 points), Klokočov (207 points), Zákopčie (200 points) and Svrčinovec (182 points) have high NCHP and developed REI. Visitors of these villages can turn their attention to various areas of tourism. There are many interesting cultural-historical monuments and protected areas; there are developed tourist and cycling trails and partly also lodging capacities. In the past, the village Stará Bystrica belonged to the most important in the whole Bystrica valley. In the $18^{\text {th }}$ century in Hámre, there was the only iron works in the whole Trenčianska county. Until the second half of the $20^{\text {th }}$ century, there was even a Jewish synagogue. Senkov valley is of historical importance; there was a stone pit with resistant sandstone used for sculptures and during the WW2, and where many inhabitants found refuge during the front movement (it is reminded by Kríž vd’aky - cross of gratitude). From our times, the most visited is the Slovak orloj/astronomical clock (the biggest wooden statue in Slovakia) with bronze sculptures and statues of apostles made with poplar wood, and the so-called astrolabe (clock face with astronomical data). Village Klokočov is located in Turzová vrchovina Mts. between Javorníky Mts. and Moravsko-sliezske Beskydy Mts., in the river basin of the river Predmieranky. Nature Reserve Klokočovské skálie (geological outcrop of spherical separation of rocks in the rock edge $300 \mathrm{~m}$ long and 15 to $25 \mathrm{~m}$ high) is another significant area. In the NNR Malý Polom, there is an interesting occurrence of conglomerate rock edges in natural forest communities of fir-beech-spruce stands. In the upper part of the river Predmieranka, there are rock rapids - uncovered rock layers stacked on top of each other. Kysuce cycling trail traverses the area, with the length of $131 \mathrm{~km}$, connects to Váh cycling trail and connects Kysuce region with Orava region. In the southern part of Jab- 
lunkovské medzihorie Mts., there is village Čierne. The most well-known tourist attraction, where events of international attendance are held, is the climb to Trojmedzie (a symbolic place where borders of three states meet - Slovakia, the Czech Republic and Poland). For cycling activities, look for cycling trail Čierne - Tri Kopce $(9 \mathrm{~km})$ and for ski activities in Ski Čierne. From the historical point of view, a well-known rampart (Šance - Valy), dating back to the $16^{\text {th }}$ and $18^{\text {th }}$ centuries, that was built to defend Silesia from Turk invasions. In the north-eastern part of Javorníky Mts. is located village Zákopčie. Rozhladňa on Martákovom kopci (Lookout tower on Marták hill) is the most visited trail, $14 \mathrm{~m}$ high and $854 \mathrm{~m}$ a.s.l. It resembles a medieval watchtower and it is built from natural stone and wood. The trail is a part of Beskydsko-Javornícka trail and it is possible to use it for cycling or in winter as a running trail.

Village Makov (199 points) and towns Čadca (197 points) and Kysucké Nové Mesto (197 points) may have middle NCHP, but they belong to villages with the most developed REI. On the north-eastern slope of Velký Javorník Mts. (1071.5 m a.s.l.) is the protected reserve Hričovec, the oldest natural reserve in Kysuce. There are precious communities of oldgrowth character. On the ridge of Javorníky Mts., there is Javornícky trail (lined by a small statue gallery in nature), connecting Kysuce and Považie, and is more than $50 \mathrm{~km}$ long. There is also the possibility of mountain cycling and an important ski resort in the area. Čadca has many significant attractions, for example, questing trail (the first in Slovakia), stone spheres in NM Megoňky (spherical separation of flysch sediments, stone spheres with diameter of 25 - $300 \mathrm{~cm}$ ), significant mineral spring (NM Vojtovský prameň and NM Bukovský prameň). In Kysucké Nové Mesto is the Kysuce observatory. Town Krásno nad Kysucou (188.5 points) has middle-high NCHP and developed REI. A big attraction here is the National History Museum, which represents the history of Kysuce region.

Fifteen villages and town Turzovka were classified into the category with middle-high or suitable PDT. Six of them and town Turzovka have middle-high NCHP and developed REI (Svrčinovec - 182 points, Korňa - 175 points, Skalité - 177 points, Turzovka - 180 points, Klubina - 164 points, Dlhá nad Kysucou - 163 points and Ochodnica - 160 points). Korniansky oil spring is one of the interesting and attractive places in these areas; it represents unique natural surface spring of light oil accompanied by emission of spontaneously combusting methane and occasional bubbling. Another significant place is the hill Živčáková (787.7 $\mathrm{m}$ a.s.l.) - a hermit place; then there is Ochodnícky prameň (spring) in Skalite and ski resorts in Ochodnica. Five villages have middle NCHP but less developed REI (Rudina - 179 points, Snežnica - 175 points, Rudinka - 158 points, Lutiše - 158 points and Lopušné Pažite - 154 points). From interesting places, it is worth mentioning fossils of small sea mammals in Snežnica, NM Kysucká brána (gorge of the river Kysuca through klippen belt), but also NM Brodňanka (limestone rocks furrowed by narrow groves) and Rochovica (the most northern thermophilic plant species). Villages Vysoká nad Kysucou and Radôstka have low NCHP and developed REI and municipalities Staškov and Dolný Vadičov have low NCHP and less developed REI. From the well-known activities in the area is, for example, a visit to the birth home of Jozef Króner (village Staškov), monuments for the fallen in Semetešská tragedy (in World War II) and memorial room of Eugen Cerman (Vysoká nad Kysucou).

Ten villages were classified as areas with low or less suitable PDT. All the villages in this 
category have low NCHP, 4 of the villages have developed REI (Zborov nad Bystricou - 141 points, Radola - 141 points, Olešná - 135 points and Nesluša - 129 points). In the church in Zborov nad Bystricou, there are stained glasses of Vincent Hložník; in village Nesluša, there is modified natural spring; and in village Radola NM Velké Ostré is located that is an example of selective weathering of limestone rocks, where softer rocks erode and the harder ones maintain their steady shape. Six villages have less developed REI (Kysucký Lieskovec - 148 points, Rudinská - 143.5 points, Povina - 142 points, Dunajov - 130 points, Lodno - 123 points and Podvysoká - 115 points).

Nowadays, the development of winter sports in Kysuce region is very good. Downhill skiing is mostly done in 10 villages - Oščadnica, Makov, Horný Vadičov, Radola, Skalité, Čierne, Ochodnica, Turzovka, Velké Ostré and Klokočov. Cycling trails, which are adjusted for cross-country skiing in winter season, and can be used as jogging trails as well. BeskydskoJavornícka trail (Čadca - Makov) and Kysuce skiing trail (Skalité - Čierne - Oščadnica) can be used for this purpose as well. Apart from the already existing resorts, based on the landscape structure, the villages Snežnica, Rudina, Rudinka, Zákopčie, Krásno nad Kysucou, Svrčinovec, Dlhá nad Kysucou and others have potential for the expansion of winter sports. According to Kmeco (2016), Kysuce region, categorised into Severopovažský region, has average potential for activities (summer activities, winter activities and activities connected to specific services of tourism).

Based on the work of Chrenka (Chrenka, 2011), the aspect of the area being on a periphery can be considered a positive factor in the development of tourism in Kysuce region. It is the location near the state borders, which means a potential of foreign visitors, and thus, economic and multicultural effect for the region. Kysuce region borders with the Czech Republic and Poland. The second aspect is the location of the mountain massif Kysucké Beskydy, which represents an attractive type of countryside for summer and winter activities.

Apart from location with regard to the main centres of settlement, accessibility of transport infrastructure is also important for the development of tourism in rural region (Michni$\mathrm{ak}, 2010$ ). Important international and intrastate sections of road infrastructure run through the area. Railways are also widely used. Traffic infrastructure is made of the roads of first, second and third class, but their technical state is in the majority of cases very bad. The problem is also the still unfinished highway D3 and freeway R5. Finishing the construction is important not only for ameliorating the traffic situation in the region, but also for the development of tourism and traffic flow through borders with Poland and the Czech Republic. Since the traffic situation is not favourable, there is need for alternative ways of transport. Significantly ecologically friendly and sustainable alternative is the development of cycling (Škorová, 2019). Bike buses have specific transport significance, since they enable comfortable access to the chosen cycling trail.

\section{Conclusion}

Kysuce region has good conditions and exceptional prerequisites for development of winter tourism - winter sports and winter hiking - mainly because of the natural territorial and climatic characteristics. There are many ski resorts with quality slopes, and that is why, it has a 
lot of visitors during the winter season. Suitable conditions are mainly for downhill and crosscountry skiing. Kysuce ski trail connects Oščadnica with another resort in Skalité - Serafinov. The most important centre of downhill skiing is Oščadnica. A significant ski centre is also Makov and other centres are in Turzovka, Vysoká nad Kysucou, Klokočov and Kysucké Nové Mesto.

Apart from the winter tourist season, even the summer part of the year should have opportunities for the development of the region. It is, however, needed to promote more and make possible such activities that would attract tourists into the area. At the same time, it is necessary to offer visitors such elements of recreational and environmental infrastructure, mainly quality lodging facilities that would make longer stays possible.

Tourist activities can be performed on 192 tourist trails with the length of $5735 \mathrm{~km}$. Kysuce cycling trail traverses almost whole Kysuce region and offers access to all beauties of the area. Its length is $131 \mathrm{~km}$ and connects to Váh cycling trail and connects Kysuce region with Orava region. Its total ascend is $620 \mathrm{~m}$, it is of moderate difficulty and on the perimeter of Kysuce, it leads on asphalt roads.

In Kysuce region, there are still many people who pursue traditional crafts, they see their importance and are trying to continue putting them into practice even nowadays. These activities may be very attractive for the development of agro-tourism. One of the main disadvantages that halt the development of agro-tourism in the region is not sufficient promotion of such form of tourism. Folk traditions and customs are on the same level; they are spread by folk bands and folklore groups. Local folk groups or bands point out peculiarities of the location of their origin and that they represent.

The least developed in the Kysuce region is agro-tourism (e.g., in villages Raková, Oščadnica, Čadca, Klokočov, Korňa, Makov and Nová Bystrica), even though the location of the region is more than favourable for such type of tourism.

By developing rural tourism and agro-tourism in Kysuce region, unemployment and moving out of population can be significantly lowered, and the character of the landscape can be maintained with all its needed functions for the environment, culture and financial welfare of the inhabitants. Within the economic-social and cultural development of the region, it is possible to create such quality of life of the inhabitants that would attract mainly the young generation. Support of small and middle businesses, development of offered services, but to a great extent effective and targeted promotion is closely connected with such a development of the region.

Development of tourism in Kysuce region should be concentrated on using its strong points, mainly the pristine nature, rich cultural-historical potential, favourable location and quite preserved customs and traditions. Kysuce region has potential to attract not only domestic, but also foreign visitors. The problem in the development of the region is its inhabitants that need to be persuaded about the qualities of the area they live in and that the region is abundant in and awaken in them self-confidence towards business activities.

Acknowledgements

The contribution was prepared within the grant project of the Ministry of Education of the Slovak Republic and the Slovak Academy of Sciences No. 2/0132/18 "Historical and present changes in the landscape diversity and biodiversity caused by natural and anthropogenic factors." 


\section{References}

Anděl, J., Balej, M. \& Suchevič S. (2008). Evaluation of the recreational potential of the landscape (in Czech). In Komplexní geografický výzkum kulturní krajiny (pp. 113-125), II. díl. Ústí nad Labem: Tomáš Mikulenka.

Bartkowski, T. (1977). Extracts to tourist geography (in Polish). Skrypty 111. Poznań: AWF.

Bína, J. (2002). Evaluation of tourism potential in the municipalities of the Czech Republic (in Czech). Urbanismus a Územní Rozvoj, 5(1), 2-11.

Butler, R., Hall, M.C. \& Jenkins J. (Eds.) (1997). Tourism and recreation in rural areas. Chichester: John Wiley \& Sons Ltd.

Cetin, M. \& Sevik H. (2016). Evaluating the recreation potential of Ilgaz Mountain National Park in Turkey. Environ. Monit. Assess., 188, 52. DOI: 10.1007/s10661-015-5064-7.

Drábová-Degro, M. \& Krnáčová Z. (2017). Assessment of natural and cultural landscape capacity to proposals the ecological model of tourism development (Case study for the area of the Zamagurie region). Ekológia (Bratislava), 36(1), 69-87. DOI: 10.1515/eko-2017-0007.

Gajdoš, A. \& Trnková M. (2016). Potential of landscape and is use in regional development on example of landscape structure changes (in Slovak). Geografické Informácie, 20(2), 82-95.

Gregorová, B. \& Korec P. (2017). Tourism as an important element of development potential of region of Eastern Slovakia (in Slovak). Acta Geographica Universitatis Comenianae (Bratislava), 16(2), 183-200.

Habán, M. \& Otapka P. (2004). Agrotourism (in Slovak). Nitra: SPU.

Chrenka, B. (2011). Peripheral areas and their representation as tourist destinations: several remarks on critical approaches in tourism geography (in Slovak). In I. Andráško, V. Ira \& E. Kallabová (Eds.), Časovo-priestorové aspekty regionálnych štruktúr ČR a SR (pp. 38-42). Bratislava: Geografický ústav SAV.

Chrenka, B. \& Ira V. (2011). Transformation of tourist landscapes in mountain areas: case studies from Slovakia. Human Geographies, 5(2), 13-20. DOI: 10.5719/hgeo.2011.52.13.

Izakovičová, Z. (2010). Evaluation of recreational potential of Trnava district (in Slovak). Ekologické Štúdie, 1(1), 51-59.

Kaspar, C. (1995). Basics of tourism (in Slovak). Banská Bystrica: Trian, Ekonomická fakulta UMB.

Klapka, P., Nováková, E. \& Frantál B. (2008). Methodical approaches to evaluating the tourism potential of the area (in Czech). Miscelanea Geographica Universitatis Bohemiae Occidentalis, 14, 65-70.

Kmeco, L. (2016). Regionalization and strategy of tourism in Slovakia (in Slovak). Acta Universitatis Carolinae luridica, 62(3), 157-168. DOI: 10.14712/23366478.2016.44.

Kopšo, E. (1992). Geography of tourism (in Slovak). Bratislava: SPN.

Mariot, P. (1983): Geography of tourism (in Slovak). Bratislava: Veda, vydavatel'stvo SAV.

Mazúr, E. \& Lukniš M. (1986). Geomorphological division of the Slovak Socialist Republic and the Czechoslovak Socialist Republic. Part of the SSR (in Slovak). 1:50 000. Bratislava: Slovenská kartografia.

Matlovičová, K., Klamár, R. \& Mika M. (2015). Tourism and its forms (in Slovak). Prešov: Prešovská univerzita.

Michniak, D. (2010). The impact of accessibility on tourism development in selected regions in Slovakia (in Slovak). Geographia Cassoviensis, 4(1), 114-117.

Mišúnová-Šulavíková, E. (2002). Cultural and historical attractions of tourism (in Slovak). In Atlas krajiny Slovenskej republiky (p. 181). Banská Bystrica: SAŽP, Bratislava: MŽP.

Molitoris, L. \& Pavlíčková K. (2013). Potential of the tourism development on the case study of microregion Velká Javorina - Bradlo (in Slovak). Acta Environmentalica Universitatis Comenianae (Bratislava), 21(2), 36-47.

Năstase, I.I., Pătru-Stupariu, I. \& Kienast F. (2019). Landscape preferences and distance decay analysis for mapping the recreational potential of an urban area. Sustainability, 11(13), 3620. DOI: 10.3390/su11133620.

Nováková, E. \& Frantál B. (2007). Natural potential of tourism in Vranovska and Podyjí regions (in Czech). In V. Klímová (Ed.), Sborník př́spevku z X. mezinárodního kolokvia o regionálních vědách (pp. 356-362). Brno: ESF MU a Stredoeurópska vysoká škola.

Novotná, M. (2007). Methodology of the evaluation of the geographic potential for tourism in the Plzeň region. Moravian Geographical Reports, 15(2), 32-39.

Otepka, P. \& Kučáková K. (2010). Rural tourism in Oščadnica village with the example of tourism facility - cottages in Kysuce region of Slovakia. Scientific Papers Management Economic Engineering in Agriculture and Rural Development, 10(3), 249-253.

Otrubová, E. (2003). Human geography, geography of foreign trade, geography of tourism (in Slovak). Košice: UPJŠ. Pásková, M. \& Zelenka J. (2012). Interpretive dictionary of tourism (in Czech). Praha: Linde. 
Pawlusinski, R. \& Piziak B. (2009). Tourism potential and possibilities of its exploitation in the Subcarpathian (Podkarpackie) voivedeship. Folia Geographica, 49(14), 223-237.

PÚSR (2015). Register of national cultural monuments - table lists (in Slovak). http://www.pamiatky.sk/sk/page/ register-nkp-tabulkove-zoznamy.

Rosič, M. \& Klamár R. (2009). The potential of tourism in the Prešov county regions. Folia Geographica, 49(14), 249-270.

Škorová, M. (2019). Cycling development project in the Kysuce region and its surroundings (in Czech). Projekt rozvoje cykloturistiky v regiónu Kysuce a okolí. Zlín: Univerzita Tomáše Bati ve Zlíne.

Trukhachev, A. (2015). Methodology for evaluating the rural tourism potentials: A tool to ensure sustainable development of rural settlements. Sustainability, 7(3), 3052-3070. DOI: 10.3390/su7033052.

Vaníček, M. (2001). Recreation and tourism in cooperation with the territorial development of Slovakia (in Slovak). Životné Prostredie, 35(5), 243-247.

Veel, A.J. (2011). Research methods for leisure \& tourism. A practical guide. Harlow: Pearson Education Ltd.

Veselý, Š. \& Dohnal M. (2015). Environmental consequences of wildlife tourism: the use of formalised qualitative models. Ekológia (Bratislava), 34(3), 260-267. DOI: 10.1515/eko-2015-0025.

Warszyńska, J. (1979). Assessment of the attractiveness of the geographical environment for the needs of tourism and recreation at various levels and stages of planning (in Polish). Skrypty 116. Poznań: AWF.

Weiss, P., Jankovičová, M., Kurčová, E., Kostovský, D. \& Vaníček M. (2005). Regionalization of tourism in the Slovak Republic (in Slovak). Bratislava: MH SR.

Wokoun, R., Malinovský, J., Damborský, M., Blažek, J. et al. (2008). Regional development, starting points of regional development, regional policy, theory, strategy and programming (in Czech). Praha: Linde Praha.

www.biomonitoring.sk

www.sopsr.sk 